\title{
Sciendo
}

\section{An Honourable U-Turn? Finland and New Europe after the End of the First World War}

\author{
Vesa Vares \\ University of Turku \\ Assistentinkatu 7 \\ Turku 20500, Finland \\ Email: vesvar@utu.fi
}

\begin{abstract}
The article deals with the situation of a small, newly- and uncertainly independent country that had a peculiar experience in the year 1918. The country had declared its independence in December 1917, had received the recognition from Soviet Russia, the Nordic countries, Germany and its allies, and France in January 1918. Almost simultaneously, it drifted to a civil war, in which both the Germans and the Russians participated. However, the Civil War was mainly a domestic concern, and the outcome was the defeat of an attempt at a socialist revolution and the victory of an extremely pro-German government that even elected a German king in Finland in October 1918. The project was never fulfilled, but the experience left an exceptional, pro-German mental heritage, to which the terms of the armistice of November 1918 was a shock. They were seen as unjust, revengeful and even petty-both by the Finnish "Whites" (non-socialists) and the "Reds" (socialists).

The Versailles Treaty in 1919 did not directly concern Finland. However, it might have done so in the question of Finnish borders, which was still partly unresolved-both in the west (a strife with Sweden over the Åland Islands) and in the east (ethnically Finnish Eastern Karelia). Moreover, the Allies were uncertain whether Finland should be considered Scandinavian or Baltic. Britain and the United States had not yet recognized Finland's independence, so in order to secure independence and territorial integrity, the Finns had to adjust to the Allies' demands and actively drive a Western-oriented policy. This was done for the same reason why the German orientation had been previously adapted-the threat of Russia and revolution-but it was psychologically strenuous for
\end{abstract}


some political circles because they felt that there was an element of dishonorable opportunism to it. However, they could offer no alternative in a situation in which a newborn state had to secure its independence and legitimacy in New Europe, adjusting to disappointments and demands.

Keywords: Finnish foreign policy, First World War, history of diplomacy, international relations, New Europe

\section{Introduction: a small state's dilemma}

One of the leading Finnish politicians, Santeri Alkio, representing the politically very republican and democratic Agrarian Union and speaking at the Finnish Parliament in August 1918, noted that "Finland lives or dies with Germany". In a similar manner, his few colleagues also declared both publicly and privately how devotedly pro-German they were and how Germany was the only friend of Finland in Europe, the only state that had any interest in defending the newly-won status of an independent Finnish state (Eduskunta, 1917 II; Keskustan ja Maaseudun arkisto, 1918). In late November 1918, two weeks after the collapse of imperial Germany, Alkio visited the residence of the French diplomatic envoy in Helsinki, where he received warm congratulations for his opposition against the then already aborted project on establishing a Finnish monarchy with a German prince as the Finnish king. He pointed to the French hosts the new borders for the Finnish state-deep in Eastern Karelia, far beyond historical Finland, hundreds of miles in the Russian territory (Kansallisarkisto, 1918b).

The following year, Alkio (1919) prophesized in a newspaper, a mouthpiece of the Agrarian Union, that a "new Europe" was emerging in Eastern Europe, and it was going to take the place of old Russia (which was to disintegrate altogether) and also of the old, war-fatigued, imperialist Western Europe. "Old Europe must die so that new Europe can be born", he emphasized with nationalistic pathos, but also with a sense of togetherness with the new, emerging nations-from Finland all the way to Ukraine and East Central Europe (Alkio, 1919). In principle, Alkio was known as a politician who had a reputation of being extremely stubborn when he had made up his mind on something. However, the situation from 1917 to the early 1920s had been perpetually experiencing various changes, and the Finnish policy had to adapt to these changing circumstances. 
It is a historical fact that, in 1918, Finland was extremely pro-German in its foreign policy. The Finnish rump parliament even elected Friedrich Karl, Prince of Hessen and the brother-in-law of Kaiser Wilhelm, the King of Finland only about a month before Germany collapsed. There was also the factor of the country swiftly changing this policy to a new course, the aim of which was to remove all this burden of German orientation and win the favour of the victorious Western great powers, especially Britain. The shift was successful: Finland got the diplomatic recognition for its independence in 1919, it was treated as a state that would be permanent and one that might serve the Western purposes, especially concerning the Western policy towards Russia. It got the important food supplies it desperately needed, it was admitted to enter the League of Nations in 1920, and, in 1921, the League decided in its favour in the Åland Islands dispute. In short, the country was accepted to become an integral part of a new international system.

How was this possible? Was this turnaround simply a result of a cynical diplomatic maneuver, a coerced act, so-called "lip-service", or a true change of convictions, or just a thing that one would have to do anyway because there was no other option? Moreover, did this take place easily or with difficulties or moral struggle? After all, in general, the Finnish identity always entails emphasizing how extremely honest the Finns are. This is represented as a special Finnish virtue, and it is taken with pride to emphasize that Finns are honest to a fault, even when it would be more advantageous to be tactically cunning. For example, Finland was the only country that dutifully paid all its debts to the United States. How is all this compatible with the U-turn of 1918-1919?

Moreover, why did the victorious great powers accept Finland as part of their own project, the aim of which was to reconstruct Europe in a very new way? What sort of goals did they have concerning Finland? Which new countries did they consider potential allies and why? Was Finland regarded as a positive part of "New Europe" or just as a country which was generally peripheral and unknown but which needed to be part of a larger system to secure the new peace and order in Europe, especially in containing the Bolshevik menace?

I will look into Finland's foreign policy especially during the years of 1918 and 1919 and into the aims of the major powers of importance to Finland, as the new state was seeking recognition of its place in Europe-and, still in many cases, recognition of its very independence. I mostly operate on the 
state level, but will also try to give a more nuanced view of Finnish politics by bringing the party-political aspect into consideration. However, first one has to refer to the general historiography of this process and its trends.

\section{An object of historical interest}

Even though the Baltic Sea area was on the sidelines from the viewpoint of the First World War, it has captured the attention of scholars of history, mostly, of course, of those coming from the countries in the area. I will now look into the Finnish historiography of the Baltic Sea region during the First World War and refer to some presentations by international scholars as well. How has Finland been perceived in this historiography? What is there still to find for historical research? (The bibliographic data of the studies can be found in the list of references below.)

To put it shortly, the Finnish scholars first concentrated on domestic events, the Civil War and the Russian aspect-how did Finland manage to become independent? Then the wider aspect and the influence of other great powers and the world war diplomacy in general became objects of interest, and the latest trend has been to move the focus on the local countries and on the collapse of societies and nation-building projects, as a wider European phenomena.

The first actual wave of research concentrated on the political events in Finland, especially on the question of independence and the escalation of the disruption of the social order, finally the Civil War (or the War of Liberation). However, in this context, it is more important to focus on how the traditional diplomacy of the great powers concerning Finland became the second objective, which meant that also the international influence was taken into account, although still in a very traditional way.

Yrjö Nurmio wrote already in 1957 about German policy in Finland and the German-Finnish relations in 1918 (Nurmio, 1957). Juhani Paasivirta, later professor of contemporary history, added the Entente aspect in 1961, and Professor Tuomo Polvinen $(1967 ; 1971)$ introduced the motives of the Soviet policy, both its Realpolitik and the world revolution aspirations in the late 1960s and early 1970s. Polvinen's results sparked some discussion, because simultaneously the political trend favored the explanation that Lenin was actually the "father" of Finnish independence. 
All these represented what you might now describe as "traditional history of diplomacy". They represented it in a time when it was still a modern way to study history, but the books largely leave the influence of domestic policy and the policy of other small states on the sidelines or altogether out of consideration.

The next level was to widen the horizons partly towards these directions. Kalervo Hovi, later professor of general history, wrote several studies on French foreign policy in the whole Baltic Sea area and in Eastern Europe, not only in Finland (Hovi, 1975a; 1984a). He referred to the wider French strategy both in the world war and later in reorganizing East Central Europe, including the Baltic Sea area. Hovi continued this line later in other books and articles, including an edited collection of articles, Relations between Nordic Countries and the Baltic Nations in the XX Century (Hovi, 1998). He also wrote shorter articles on the recognition of Finnish independence by Austria-Hungary (Hovi, 1971) and Italy (Hovi, 1975b). Eino Lyytinen (1980) wrote his dissertation about British policy towards Finland and Olavi Hovi (1980) about the same policy towards the Baltic countries. Jorma Kalela, later professor of contemporary history, belongs to this group as well. He wrote his dissertation about Finnish-Swedish relations, using the traditional methods of diplomatic history but with a greater focus on the domestic policy influence of the two countries (Kalela, 1971).

The latest wave of research devoted more attention to the local players than the great powers. Kalervo Hovi was one of the pioneers in this as well, specializing in the Polish perspective (Hovi, 1984b). Seppo Zetterberg (1977; 2018), later professor of general history, wrote about Finnish-Estonian relations. But it was especially the younger generation, for example Heikki Roiko-Jokela (1999), Marko Lehti (1999) and Esa Sundbäck (2001), who focused their research on the Baltic area in the 1990s. Finland and the Baltic connections or some Baltic country sometimes became the main point of interest, and the economic interests behind the Great Power policy were taken into account more than before as well. Mari Vares and Vesa Vares have made comparisons between Finland and other countries that became independent at the same time in their recent book Valmis valtioksi-Suomi ja eurooppalainen itsenäisyysaalto (Vares \& Vares, 2019).

Here one must also refer to some recent studies that have looked into the events in the Baltic area in 1917-1920 as a geographical entity and as parts of the world war and the time of upheaval after the war. Professor Andres Kasekamp (2010) represents this approach with an emphasis on the case 
of Estonia. A Polish researcher and later diplomat Jarosław Suchoples (2000) published a book about Finnish-American relations. One must also mention John Hiden's and Patrick Salmon's book on the history of the Baltic States, The Baltic Nations and Europe. Estonia, Latvia and Lithuania in the Twentieth Century (Hiden \& Salmon, 1991), although it is more general in nature and the years 1917-1920 cover only a minor part of it.

European research has occasionally made an effort to place the Baltic Sea events in a larger context as well-sometimes with more and sometimes with less success. For example, one of the present-day authorities of the history of 1917-1920, Professor Margaret MacMillan (2002) concentrates on the diplomacy of peace treaties, but also briefly mentions the Baltic Sea countries as part of the arrangement. Professor Robert Gerwarth (2016) also briefly deals with the cases of Finland and the Baltic region in his book about the year 1918 and its revolutionary aftermath.

A more recent and interesting approach has been made by Polish scholars Włodzimierz Borodziej and Maciej Górny (2018a; 2018b), who have abandoned the idea that the world war would have lasted from 1914 to 1918. According to them, the Balkan Wars in 1912-1913 were the starting point, and the revolutions and civil wars after 1918 an aftermath of what was still essentially a part of the world war. They mention, for example, also the Finnish Civil War and the events in the Baltic States. However, in the Finnish case, all these scholars use existing literature but have not been able to use original Finnish materials. (Borodziej \& Górny, 2018a; 2018b) Still, the aspects are new and still relatively pioneering in Finnish research as well.

Thus it can be said that, when it comes to foreign policy and the history of diplomacy during the First World War and immediately after it, most aspects of Finland and the Baltic Sea area have been studied. However, there are still points of interest that have not been touched as thoroughly as can be done. These include, for example, the influence of party politics in Finland (and in other countries) in the events of 1917-1920, the wider aspect of the European breakup of societies and empires and the impact of revolutionary movements and their radicalized counterforces, especially during 1919 and 1920, the national stereotypes, the policy of remembrance and commemoration, etc. 


\section{3. "The First World War in Finland in 1918?"}

At first, Finland had largely escaped the grievous outcomes of the world war. It was an autonomous part of Russia, and the war had not directly touched it because of the geographical advantage of being in the periphery. The Finns did not even have to serve in the Russian army, because the Russians considered them politically highly untrustworthy. This was due to the long political struggle between Finland and Russia, during which Russia tried to cancel Finnish autonomy and force Finland to submit to Russian legislation. In the military sector, the Finns only had to pay contributions to the Russian army to compensate for the lack of military service, and during the war about 500 Finns enlisted voluntarily to the Russian army. At the same time, 2,000 travelled in secret to Germany in order to get military training. This was intended for a rebellion in Finland (see, for example, Luntinen, 1984; Hoppu, 2005. Here, as in many other cases, I refer to the whole book rather than to specific pages, because the reference applies to very general assessments rather than particular details).

Actually, in 1914-1916, Finland had only benefited from the war. The Russian army paid handsomely for the products of Finnish industry, the 125,000 men Russian army in Finland was a good customer also in private markets, and the fortification projects in Finland created plenty of jobsso many that the Russians eventually had to import Chinese workers to Finland.

However, the economic situation gradually declined, and when the Russian emperor was overthrown in 1917, all the bitter domestic political contradictions emerged to the surface (see, for example, Haapala, 1997). The fact that Finland declared itself independent in December 1917 did not ease this domestic pressure. Finally, in January 1918, this led to a very bitter and bloody Civil War between the social democrat Reds and the non-socialist Whites, who held the government and the majority in the parliament. After the Bolshevik coup in Russia, the Russians had encouraged the Red Finns to follow suit and gave them some assistance during the Finnish Civil War, and simultaneously Germany sent 12,000 regular troops to fight on the side of the White Government. In May 1918, the Whites and the Germans had won the war, and Finland adopted a very pro-German foreign policy orientation (see, for example, Haapala, 1997; Vares, 1998; Hentilä \& Hentilä, 2016). 
This also led to the monarchist project referred to above. The motives and logic can be best seen in the argumentation of the conservative Prime Minister J. K. Paasikivi:

We have to be thankful for Germany for everything. [...] Our independence rests entirely on German support, because as sure as the autumn follows the summer, Russia is going to try to reconquer and annex us. If Germany does not help us, our independence is going to be only a short episode in our history. (Kansallisarkisto, 1918a)

Or as his party colleague put it:

I'm not an enemy of England. I've admired their colonial policy more than almost any policy in Germany. But who can close his eyes from the fact that England considers it necessary to reach its goals over our dead body? (Rantakari, 1918a-1918d)

The idea that Germany could be a long-lasting security defense against Russia seems far-fetched and short-sighted now. After all, Germany collapsed already in November 1918. However, when the German orientation was adopted, the global situation seemed very different. Germany was launching its Spring Offensive and was deep in enemy territory everywhere, and the Finns had little chance to see how the German homefront was getting fatally exhausted. In autumn 1918, the difficulties could be seen, but no collapse seemed imminent-rather a negotiated peace, which would leave Germany the strongest power in Northern and Eastern Europe. And, evidently, many Finns also took very seriously the idealistic view on loyalty. As a conservative MP noted in his diary about the demands that Finland should change its course of foreign policy when Germany was in trouble: "Who in the world would even be able to bring himself to look at us in our eyes if we now abandon the friendship of Germany?" (Helsinkin Yliopiston Kirjasto, 1918)

All this made Finland very suspect in the eyes of practically all other nations in the Baltic Sea area. Sweden thought the German influence was too strong in Finland and its press maintained that the Red and White Terror had revealed an unpleasantly primitive and malicious side of the Finnish national character. Because of the German influence and the British interests in the Pechenga and Murmansk areas, Britain came close to declaring war against Finland in summer 1918, and even France, who had recognized Finland's independence in January 1918, froze relations after Prince Friedrich Karl of Hessen had been elected King of Finland (for further information, see Lyytinen, 1980; Vares, 1998). 
The German revolution and collapse came as a total shock to the Finnseven to the republicans, who had opposed the project of monarchy but had, like Alkio, eagerly supported the pro-German foreign policy as such.

Nevertheless, it is fair to say that the war in Finland would hardly have been possible without the impact of the First World War. Therefore, some Finnish scholars have lately toyed with the idea of introducing yet another name for the Finnish war- "the First World War in Finland".

\section{The shock of the armistice and Versailles}

The Finnish reaction to the German collapse did not limit itself only to shock or to sympathy towards the Germans. This loyalty manifested itself also in the fact that the Finnish press and public opinion granted no mercy whatsoever to the armistice treaty in November 1918 or the Versailles Peace Treaty in 1919. Almost without exceptions, all Finnish political circles denounced the treaty as unjust, unfair, malicious, revengeful, petty and fatal to all of Europe in the sense that it left Germany no chance to survive as a nation. In short, it pushed Germany to the brink of Bolshevism (Vares, 2018, pp. 78-102).

The monarchist right-wing newspapers and politicians were especially shocked. Their newspapers loudly declared their sympathies to suffering Germany and to its heroic battle against overwhelming odds, some of them pitied even the Kaiser. They were morally outraged and deeply disappointed, and as one of the leading female non-socialist politicians wrote in her diary: Germany was supposed to be so strong that it would never fall (Kansallisarkisto, 1918c). Now the ground was vanishing under the feet of those who had believed so-including her. Because of this, many felt the German disaster as it were their own. A Finnish newspaper wrote that "the malicious victors are bleeding the magnificent German lion dry, so that only a shadow of life would remain possible for it" (Karjala, 1918).

The real culprit was France-a right-wing activist daily wrote how the armistice conditions reflected the "feminine revengefulness of France" (Uusi Päivä, 1918). At this stage, no sympathy was expressed to those new countries which were now emerging on the map of Europe. With the exception of Estonia, they were rather seen as petty and devious vassals of 
the victorious powers who did not realize that Germany had liberated them from the Russian threat.

This was to be expected from the monarchists, most of whom had always sympathized with Germany. But the same moral abhorrence could be founded in most republican reactions. After all, they had experienced the German intervention on the side of the legal White government during the Finnish Civil War as an act of liberation. The non-socialist Finnish opinion was bitterly divided in the monarchy/republic issue, but it had been unanimous in that Finland needed the protection of a Great Power against Russia. Russia was evil, it would try to reconquer Finland eventually, no matter the outcome of its own revolution. Hence the collapse of Germany robbed Finland of a shield against both external threat and internal convulsion. Even though old Germany had perhaps not been as democratic and liberal as Britain or France, why punish new Germany, which was going to be democratic? For example, Alkio had visited the French embassy after the collapse of Germany in order to collect political points for Finland from the victorious powers, but he also deplored the Treaty of Versailles (see Ilkka, 1918). Only gradually he began to see the Baltic countries and Poland as new potential allies.

The collapse of Germany robbed Finland of a role model also in another sense. For a while, Germany had seemed to be the model society that would never collapse.

This did not only mean politics. Germany had been the role model also in many other issues: as a civic society, in science, as the original land of Lutheranism, as a heroic military power which had managed to defend itself against almost the whole world, etc. German was also the first foreign language in Finnish secondary schools. Moreover, the nationalist philosophy of Hegel and Herder had been the models for the nineteenth-century Finnish nationalist ideologists J. W. Snellman and Yrjö Sakari Yrjö-Koskinen. And not only them, but also social reformists like Schmoller, Wagner and Sombart. Germany was not only the land of power politics and soldiers, but also of religion, culture and science. It did not have only Moltke, but also Goethe, Schiller, Robert Koch, Georg Jellinek and many, many others. For the Finnish elite, Germany was "familiar", whereas England and France were much more distant and strange. In short, England was appreciated by the businessmen and France by the artists, but most of the Finnish political elite neither understood nor appreciated either. 
If all this could collapse, and in such a short time, what could you rely on? Who would guard the decent, established world order?

Even the social democrats, who had lost the Civil War and were now making their comeback to the political scene, had nothing good to say about the armistice and the Versailles treaties, nor did they appreciate the dominant role of the Western Powers. They did not feel any sympathy towards the Kaiser or the old German government, nor did they share the panic of the bourgeoisie in security policy; according to their view, Russia would not invade Finland as long as the Bolsheviks held the power. But they argued that the victorious powers made new Germany-ruled by German social democrats-pay for the sins of its predecessor. The harsh conditions imposed on Germany would endanger the fragile German democracy. Besides, as the leading newspaper of the social democrats argued, the Western Powers had not really fought for freedom and democracy, but for their own selfish, imperialist interests. (Suomen Sosialidemokraatti, 1918)

The only exception were the Finnish communists. According to their newspaper, the Versailles Treaty was a good thing because it would completely destroy the political role of German reactionaries. It would also speed up the revolution because living conditions in Europe would deteriorate (Savon Kansa, 1919; Suomen Työmies, 1920). The viewpoint was extremely ideological and meant in practice that the worse, the better-because this would bring the communist revolution nearer.

\section{The situation without options}

The pro-German Finnish stigma of 1918 was difficult to shake off also in the eyes of the victorious powers. To them, Finland had been a German satellite, and like the Baltic States, it was not by all certain that it will be able to maintain its independence and social order. After the shock of November 1918, the Finns had to adjust to these circumstances, and actually they did this relatively speedily—at least on upper level.

The pro-German Regent and government were both replaced by new ones that were more acceptable to the victorious powers. C. G. E. Mannerheim, who had served 30 years in Imperial Russian Army and had been Commanderin-Chief of the Finnish White Guard during the Civil War, was elected the new Regent by the parliament. The pro-German circles were gradually 
ousted from the government, the rump parliament was dissolved and new parliamentary elections were declared. In the elections, social democrats made a strong comeback, winning $40 \%$ of the seats. The German troops had left Finland in December 1918 and the King-elect Prince of Hessen released the Finnish Parliament from all duties caused by his election. Some military instructors stayed at first, but even they were forced to resign after the protests of British and especially French diplomats. (Hentilä \& Hentilä, 2016, pp. 323-344)

All this was painful for many who had admired Germany or at least had reasoned that no matter what one thought about the Germans, they were the lesser evil compared to Russians. But even most of the emotionally proGerman circles knew that there was no alternative to the change of policies. The whole point of the German orientation had been that it was a way to bind a Great Power to protect Finland against Russia and to prevent a new rebellion. Germany had been the only possible alternative, and even if this would mean German influence in Finland, this was considered unavoidable as the Russian threat was concrete and imminent. Now Germany clearly had neither the strength nor the will to fulfil this role. Germany had lost the war, it was the new leper of international politics and on the brink of revolution itself. (Vares, 2018, pp. 78-86)

Finland's survival as an independent nation now depended on other great powers. It depended on diplomatic recognition by the Western countries and quite specifically on Western food supplies when facing famine. Great Britain, the United States and Italy had not even recognized the independence of Finland. France had done this in January 1918, but even France had put the diplomatic relations on ice. Thus those who emphasized the shift in policies had a very strong argument: if Finland does not abandon the pro-German past and respond to the demands of the Western Powers, what would prevent them from "selling" Finland to Russia, especially if the anti-Bolshevik forces win the Russian Civil War?

It was by no means certain that Finland would be rehabilitated to the new order. The victorious powers had other favorites who had been on the "right" side. Margaret MacMillan (2002, pp. 229, 230) refers to the Poles and especially Czechs. Also the Yugoslavs, Estonians, Latvians and Lithuanians were on the "right side" compared to the Finns, who had been pro-German. The British Consul in Helsinki described the change of government as replacing a blind horse with a one that was one-eyed, and Foreign Minister Curzon maintained that the Finnish position was not secure (Jägerskiöld, 
1967; 1969; Bell, 1950, p. 50). Head of intelligence, J. Y. Simpson considered some Finnish ministers as a burden to the recognition of independence and warned of the influence of Germany, Bolsheviks and the pro-German Jägers in the Finnish army (The National Archives of the United Kingdom, 1919).

In February 1919, France even demanded the resignation of four Finnish ministers, and even British diplomats referred to these ministers as obstacles to a recognition of independence. However, it withdrew the demand after Mannerheim gave his guarantees on the reliability of these ministers, and the government was about to be changed altogether soon anyway, since the parliamentary elections were approaching (Paasivirta, 1961, pp. 121-124; Vares, 1994, pp. 16-23).

One can also clearly see that both the old enemy image, previous propaganda and a patronizing von oben attitude towards smaller nations was as strong among the victorious powers as it had been among Germans. Even later, during the 1920s and 1930s, it is typical to see that the representatives of all great powers very often assumed that if Finland made any active move in its foreign policy, it was bound to be a result of influence by other great powers. For the Western powers this meant the German menace.

Moreover, there were other risks. Sweden was claiming the Åland Islands for itself, and Finland needed the support of the great powers if it wanted to guard its territorial integrity — or to be admitted to the League of Nations. All this meant that Finland had very little space to maneuver.

The only advantage to Finland in this situation was that it had some merits as well. It was traditionally considered more Western or at least more Scandinavian than the Baltic nations, and although it had previously never been an independent state, it had been an autonomous Grand Duchy for a century. It was thus better prepared for independence and nationbuilding than the other newly-independent countries. Especially Britain had also financial interests in Finland and more widely in the Baltic Sea area (Sundbäck, 2001).

The best political card was that Finland had defeated Bolshevism and stopped it from spreading westwards. It could also serve as a useful support and link-or even instrument-if the Western powers wanted to attack the Red St. Petersburg. All in all, Finland had to be taken into account in some way if one wanted to keep the Bolsheviks at bay and to rearrange the remnants of the Russian and German power in the Baltic Sea area and make the area politically and economically functioning in the new situation. 
In May 1919, the Western powers thought they had seen enough proof of Finnish reliability and recognized the country's independence. Finland was now considered a country which would survive as an independent nation and would be a sort of northern equivalent to Poland - the attitude towards Estonia, Latvia and Lithuania was far more doubtful.

\section{Political parties adapting to the situation}

In the end, also the Finnish party political level could put up with the change of policies, even if some Finnish diehards considered it shameful that Finland had "abandoned" Germany and mocked that Foreign Minister Carl Enckell had been "the British vice consul in Finland" (Kansallisarkisto, 1919). But no one had been able to show any credible option. Besides, even most of the pro-German conservatives had traditionally looked at foreign relations very rationally and coolly: a small country cannot base its foreign policy on emotions. This attitude was evident especially among the older generation who very much decided the political course. They were used to adapting to the situation: first to the Russian pressure, then to the German influence, and now they were looking for new powerful guarantees for Finnish independence. This time they favored England; France, on the other hand, was still mistrusted. (Vares, 1993, pp. 419-443)

The social democrats continued to distrust the Western powers and pity the destiny of the German working class. However, they moved to a sort of logic of "lesser evil" in the same way as the conservatives. Their policy line was still to emphasize that the West represented imperialism; but it was the only force which could keep the German reactionaries, German communists and Russian Bolsheviks at bay. And even though British and French political systems had their shortcomings, they were democratic enough to guarantee that the labour movement would gain more and more influence. However, this was a gradual change that took place over years.

The shift was especially easy for the liberals. They took over the newlyestablished Foreign Ministry of Finland in spring 1919, and there were also some genuinely pro-British and pro-French personalities among them. The Liberals were a small party, but they had the tactically useful position in the political center. They got the posts of prime minister and foreign minister and the even more powerful presidency in July 1919, when Regent Mannerheim was rejected in the first presidential elections and was replaced by a long- 
standing liberal politician K. J. Ståhlberg (Karimäki, 2016). One might say he was sort of a Finnish Masaryk.

Moreover, the new Foreign Minister Rudolf Holsti, also a liberal, was one of the very few Finns who actually understood and admired the British and French policy. He had been in London during the World War, and he was a pro-Entente man to the point of piousness. He disliked Germans no matter the political orientation in Germany and had a wide strategy of forming an alliance with the Baltic States and Poland, perhaps also with Romania and Czechoslovakia, under the protective umbrella of Britain and France. This would save Finland from both the Russian and German influence and also contribute to the stability of the new European order by isolating the two potentially dangerous nations from each other. In short-a small state actively in the cordon sanitaire (Roiko-Jokela, 1995, pp. 111-136). No wonder that a British Foreign Office civil servant noted: "it seems that he does not actually care of any other country's opinions but ours in foreign policy" (Hardinge, 1961).

The British and French diplomats relied on Holsti and at first believed his constant warnings that the conservatives had not really changed their loyalties but were only biding time to adapt a German or even Russian line in the future. This was not actually true, and you might even call it blackballing, but because of the events in 1918 it had credibility in the British and French eyes. (Vares, 1994, pp. 26-30)

The other political party that supported Holsti's foreign policy, the Agrarian Union-which was now the true "natural party of government" in the sense that it had become the dominant non-socialist party-was actually not interested in foreign policy. However, it was the ally of the liberals in domestic policy, it thought that there was a "new Europe" emerging in Eastern and Central Europe on agrarian, democratic values, and it conveniently forgot its own pro-German past. Thus the new orientation and the person of Holsti suited its political needs very well. (For further information of the Agrarian Union during these years, see Mylly, 1989.)

Especially after 1919, a new orientation, the so-called border state orientation gathered momentum. Moreover, it seemed that it was the only alternative left in the early 1920s. Germany had collapsed, Britain (not to mention the United States) was not interested in securing the independence of a small, peripheral country, there was still coolness in the Finnish-Swedish relations because of the Åland Islands issue, and the League of Nations was not yet 
a credible option to guard the security of small nations. The Finns had concluded peace with the Soviet Union in Dorpat in October 1920, but the relations remained cold, suspicious and strained: small Finnish volunteer units made sporadic interventions to Eastern Karelia, and Soviet Russia was the safe haven for the Finnish revolutionary communists who were waiting for a revanche of 1918 .

In 1922, the relations were so strained that Finland clutched at the last straw. Holsti signed a treaty of political alliance with Estonia, Latvia, and Poland in Warsaw. It seemed that Finland had now chosen its reference group, perhaps also on a more general ideological level than only in security policy. However, Holsti's problem was that his political backing was not sufficiently wide in the party political level, and he was also a bit troublesome as a person-not prone to make compromises when he thought he was right. The conservatives thought he was a Germanophobe who was leading Finland to the position of a French and Polish satellite, and the social democrats did not want any political or military treaties. At the end of the day, both were essentially pro-Scandinavian. Now, finally, the opposition united against Holsti and the parliament not only refused to sign the treaty, but also gave Holsti a vote of no confidence in May 1922. (Vares, 1993, pp. 598-603)

\section{Conclusion}

The shift from one foreign policy to another was not, in the end, as painful for the Finns as they had first assumed. Germany made it easier for them by sinking into disorder and starting to fraternize with the Soviets- the only threat against Finnish independence. Also the legacy of small state realism and the lack of options convinced all relevant political forces of the need for a new orientation.

The formerly pro-German circles now sought for British favor as well. After all, Great Britain indeed had quite many good points, in their view. Britain was the best customer of Finnish products, it was the country that was always on the winning side, it had formed the greatest empire since the Romans, it was a solid society that honored traditions and a nation that took care of individual freedom and democracy in its own country. It would gladly have been given the role of 1918's Germany, if it had been interested. However, this was not in the British tradition. 
Britain and France were convinced that, in the long run, Finland was a useful bulwark against Bolshevism and more likely to survive than Estonia, Latvia and Lithuania-it was a sort of smaller Poland. As long as it fulfilled this role, it was not even important which political party took care of the job. Even the former pro-German conservatives were rehabilitated in a few years. The British envoy George Kidston confessed already in 1920 in his report to the Foreign Office that they seemed totally reliable and had only acted in their own country's interest in a difficult situation, and they had such a strong position in the Finnish society that it would be difficult to run things without them. As Kidston (1920) noted: "People who have a notorious pro-German reputation now eat from my hand [...] or, which is even more telling, invite me to eat at their cost" (The National Archives of the United Kingdom, 1920).

It was the Estonians, Latvians and the Poles that became the losers in their hopes to win Finland for their security solutions. This was mainly because the majority of the Finns rather identified themselves with the Scandinavians, especially the Swedes, regardless of the Aland Islands dispute or the language questions in Finland and Sweden. Compared to this, Eastern Europe did not seem equally developed, civilized, stabilized and democratic. Moreover, its security seemed even more threatened than that of Finland.

The only new country that had instantly benefited from the new, republican Finland was Estonia. The sense of romantic national kinship, strategic advantages and the sense that Finnish aid to Estonia in the latter's struggle for independence against Bolshevik Russia would be appreciated by the victorious Western powers made Finland send arms and 4,000 volunteers to the Estonian War of Liberation (1918-1920). It was only later, in 1920 1921, when the cooperation between the new "border states" began to take a more stabilized form, and even then it failed to produce a satisfactory option to Finnish security needs. The quest for security continued by other means in the 1920s and the 1930s.

Vesa Vares is a professor of contemporary history at the University of Turku, Finland. He is former head of the Department of Philosophy, Political History and Political Science and former Vice Dean of the Faculty of Social Sciences at the University of Turku. He has specialized in the history of political parties, Finnish domestic and foreign policy, FinnishGerman relations, history of universities, sports, police and cinema and has written several biographies. 


\section{References}

Alkio, S. (1919), Lead article, Ilkka, 16 December.

Bell, H. M. (1950), Land of Lakes: Memories Keep Me Company, London: Robert Hale Ltd.

Borodziej, W. \& Górny, M. (2018a), Der vergessene Weltkrieg. Band I. Imperien 1912-1916, Darmstadt: wbg Theiss.

Borodziej, W. \& Górny, M. (2018b), Der vergessene Weltkrieg. Band II. Imperien 1917-1923, Darmstadt: wbg Theiss.

Eduskunta (1917), Sessions of the Finnish Parliament, 1917 II, Protocol, pp. 11851187, 1247, 1256, 1280, 1281, 1332, 1661, 1691, 1693, 1820, Parliament of Finland, Helsinki.

Gerwarth, R. (2016), The Vanquished: Why the First World War Failed to End, 1917-1923, London: Penguin Books.

Haapala, P. (1997), Kun yhteiskunta hajosi. Suomi 1914-1920 [When the society collapsed: Finland 1914-1920], Helsinki: Kleio ja Nykypäivä.

Hardinge, A. (1961), 'Hardinge to Acton 21 April 1920,' in R. Butler \& J. P. T. Bury (eds.) Documents on British Foreign Policy, First Series: 1919-1939, vol. XI: Upper Silesia, Poland and the Baltic States, London: HMSO, pp. 295-298, no. 256.

Helsinkin Yliopiston Kirjasto (1918), Paavo Virkkunen's diary, 12 October 1918, Virkkunen papers, k. 157, Library of the University of Helsinki.

Hentilä, M. \& Hentilä, S. (2016), Saksalainen Suomi [German Finland], Helsinki: Siltala.

Hiden, J. \& Salmon, P. (1991), The Baltic Nations and Europe. Estonia, Latvia and Lithuania in the Twentieth Century, London: Routledge.

Hoppu, T. (2005), Historian unohtamat. Suomalaiset vapaaehtoiset Venäjän armeijassa 1. maailmansodassa [Forgotten history: Finnish volunteers in the Russian army in World War I], Helsinki: Suomalaisen Kirjallisuuden Seura.

Hovi, K. (1971), Itävalta-Unkari ja Suomen itsenäistyminen [Austria-Hungary and the independence of Finland], Eripainossarja no. 16, Turku: Yleisen historian laitos, Turun yliopisto.

Hovi, K. (1975a), Cordon sanitaire or barrier de l'est? The emergence of the New French Eastern European Alliance Policy 1917-1919, Turun yliopiston julkaisuja, Annales Universitatis Turkuensis, Series B, vol. 135, Turku: Turun yliopisto.

Hovi, K. (1975b), Italia ja Suomen itsenäistyminen. Lähettiläsraportit [Italy and the independence of Finland: ambassador's reports], Eripainossarja no. 29, Turku: Yleisen historian laitos, Turun yliopisto. 
Hovi, K. (1984a), Alliance de Revers. Stabilization of France's Alliance Policies in East Central Europe 1919-1921, Turun yliopiston julkaisuja, Annales Universitatis Turkuensis, Series B, vol. 163, Turku: Turun yliopisto.

Hovi, K. (1984b), Intressensphären im Baltikum. Studia Historica 13. Finnland im Rahmen der Ostpolitik Polens 1919-1922, Societas Historica Finlandiae, Helsinki: Suomen Historiallinen Seura.

Hovi, K., ed. (1998), Relations between Nordic Countries and the Baltic Nations in the XX Century, Turku: University of Turku.

Hovi, O. (1980), The Baltic Area in the British Policy 1918-1921 I. From the Compiègne Armistice to the Implementation of the Versailles Treaty, Studia Historica 11, Societas Historica Finlandiae, Helsinki: Suomen Historiallinen Seura.

Ilkka (1918), Lead article, Ilkka, 12 November.

Jägerskiöld, S. (1967), Mannerheim 1918, Keuruu: Otava.

Jägerskiöld, S. (1969), Valtionhoitaja Mannerheim [Regent Mannerheim], Keuruu: Otava.

Kalela, J. (1971), Grannar på skilda vägar. Det finländsk-svenska samarbetet I den finländska och svenska utrikespolitiken 1921-1923 [Neighbors on separate roads: Finnish-Swedish cooperation in the Finnish and Swedish foreign policies 19211923], Historiallisia Tutkimuksia 89, Helsinki: Suomen Historiallinen Seura.

Kansallisarkisto (1918a), Letter to Hannes Gebhard, 31 August 1918. Gebhard papers, k. V:9, The National Archives of Finland, Helsinki.

Kansallisarkisto (1918b), Santeri Alkio's diary, 22 November 1918, Alkio papers, OS 77, The National Archives of Finland, Helsinki.

Kansallisarkisto (1918c), Tekla Hultin's diary, 10 October 1918, 11 October 1918. Hultin papers, The National Archives of Finland, Helsinki.

Kansallisarkisto (1919), S. J. Pentti to A. H. Saastamoinen, 25 February 1919. Saastamoinen papers, k. 10, The National Archives of Finland, Helsinki.

Karimäki, J. (2016), Tulevaisuuden lähtökohdista kansanvallan kolmiliittoon. Kansallinen Edistyspuolue ja kansallisen eheytymisen politiikka 1919-1939 [Future perspectives for the democratic triple union. The National Progressive Party and the national integration policy 1919-1939], Annales Universitatis Turkuensis, 415. Turku: Turun yliopisto.

Karjala (1918), Lead articles, 21 November and 15 December.

Kasekamp, A. (2010), A History of the Baltic States, Palgrave Essential Histories Series, Basingstoke \& New York: Palgrave Macmillan.

https://doi.org/10.1007/978-0-230-36450-9

Keskustan ja Maaseudun arkisto (1918), Protocol of the negotiations of the nonsocialist parties in the House of the Estates, 8 July 1918, Archive of the Center Party and Countryside, Helsinki. 
Lehti, M. (1999), Baltic League as a Construct of the New Europe. Envisioning a Baltic Region and Small State Sovereignty in the Aftermath of the First World War, Frankfurt am Main: Peter Lang.

Luntinen, P. (1984), Sotilasmiljoonat [Military millions], Helsinki: Suomen Historiallinen Seura.

Lyytinen, E. (1980), Finland in the British Politics in the First World War, Annales Academiae Scientiarum Fennicae, Series B, Helsinki: Suomalainen Tiedeakatemia.

MacMillan, M. (2002), Paris 1919: Six Months that Changed the World, New York: Random House.

Mylly, J. (1989), Maalaisliitto 1918-1939: Maalaisliitto-Keskustapuolueen historia 2 [Agrarian Union 1918-1939: History of the Agrarian Union and Centre Party], Helsinki: Kirjayhtymä.

Nurmio, Y. (1957), Suomen itsenäistyminen ja Saksa [Independence of Finland and Germany], Porvoo: WSOY.

Paasivirta, J. (1961), Ensimmäisen maailmansodan voittajat ja Suomi. Englannin, Yhdysvaltain ja Ranskan sekä Suomen suhteita vv. 1918-1919 [Winners of the First World War and Finland: Relations between the Great Britain, the United States and France and Finland, 1918-1919], Porvoo: WSOY.

Polvinen, T. (1967), Venäjän vallankumous ja Suomi 1917-1920. I. Helmikuu 1917 - toukokuu 1918 [The Russian Revolution and Finland 1917-1920. I. February 1917-May 1918], Porvoo: WSOY.

Polvinen, T. (1971), Venäjän vallankumous ja Suomi 1917-1920. II. Toukokuu 1918 - joulukuu 1920 [The Russian Revolution and Finland 1917-1920. I. May 1918-December 1920], Porvoo: WSOY.

Rantakari, K. N. (1918a), Article, Karjalan Aamulehti, 30 June.

Rantakari, K. N. (1918b), Article, Satakunnan Kansa, 11 July.

Rantakari, K. N. (1918c), Article, Uusi Aura, 11 July.

Rantakari, K. N. (1918d), Articles, Wiipuri, 30 June, 7 July.

Roiko-Jokela, H. (1995), Ihanteita ja reaalipolitiikkaa. Rudolf Holstin toiminta Baltian maiden kansainvälisen de jure -tunnustamisen ja reunavaltioyhteistyön puolesta 1918-1922 [Ideals and Realpolitik. Rudolf Holst's work for international de jure recognition of the Baltic States and co-operation with peripheral states 1918-1922], Studia Historica Jyväskyläaensia, Jyväskylä: Jyväskylän yliopisto.

Savon Kansa (1919), Lead article, 3 June.

Suchoples, J. (2000), Finland and the United States, 1917-1919. The Early Years of Mutual Relations, Bibliotheca Historica 56, Helsinki: Suomalaisen Kirjallisuuden Seura. 
Sundbäck, E. (2001), Finland in British Policy: British Political and Economic Interests Regarding Finland in the Aftermath of the First World War, Helsinki: Finnish Academy of Science and Letters.

Suomen Sosialidemokraatti (1918), Lead articles, 9 December, 10 December, 12 December.

Suomen Työmies (1920), Lead article, 9 November.

The National Archives of the United Kingdom (1919), Memorandum, 23-25 January 1919, FO 371/ 3730, Foreign Office Papers, London.

The National Archives of the United Kingdom (1920), Letter from George Kidston to Sir Basil Thomson 18 July 1920, Curzon papers, FO 800/153/45, London.

Uusi Päivä (1918), Lead article, 13 November.

Vares, M. \& Vares, V. (2019), Valmis valtioksi - Suomi ja eurooppalainen itsenäisyysaalto [Ready to become the state-Finland and the European wave of independence], Jyväskylä: Docendo.

Vares, V. (1993), Konservativi ja murrosvuodet: Lauri Ingman ja hänen poliittinen toimintansa vuoteen 1922 [The Conservative and the years of transition, Lauri Ingman's political activities until 1922], Historiallisia tutkimuksia, 174. Helsinki: Suomen Historiallinen Seura.

Vares, V. (1994), Lontoon tie: Iso-Britannian diplomaattien rooli Suomen sisäpolitiikassa 1919-24 [Road to London: The role of British diplomats in Finnish domestic affairs 1919-24], C 47, Turku: Turun yliopisto.

Vares, V. (1998), Kuninkaantekijät. Suomalainen monarkia 1917-1919. Myytti ja todellisuus [Makers of the king. Finnish monarchy 1917-1919. Myth and reality], Porvoo: WSOY.

Vares, V. (2018), Viileää veljeyttä. Suomi ja Saksa 1918-1939 [Cool brotherhood. Finland and Germany 1918-1939], Helsinki: Otava.

Zetterberg, S. (1977), Suomi ja Viro, 1917-1919: Poliittiset suhteet syksystä 1917 reunavaltiopolitiikan alkuun [Finland and Estonia, 1917-1919: Political relations from autumn 1917 to the beginning of peripheral state policy], Historiallisia Tutkimuksia 102, Helsinki: Suomen Historiallinen Seura.

Zetterberg, S. (2018), Viro ja Suomi 1917-20 [Estonia and Finland 1917-20], Jyväskylä: Docendo. 